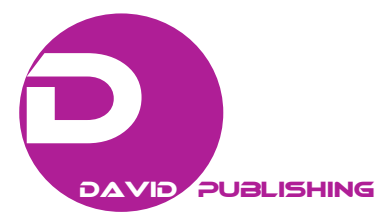

\title{
Sports Tourism Development in Indonesia
}

\author{
Soedjatmiko \\ Sports Coaching Education Department, Sport Science Faculty, Semarang State University, Semarang, Central Java 50229, \\ Indonesia
}

\begin{abstract}
Sport tourism has a good effect against the development of tourism in general. Sport and tourism are the two disciplines and two different studies but they can be put together so that mutually beneficial. In sports, there are some tourism elements. Conversely through tourism, sports can be nurtured and developed. Another goal is to serve as a tool to introduce and to recognize sport, improve fitness and preparation exercise. In 2006, the Indonesian government began to develop sports industry which is a new field of study in this country. Ministry of Youth and Sports launched a resurgence sports industry in Indonesia. Sport Tourism is very likely developed in Indonesia. Indonesia is a country rich in natural resources which are very beautiful. Indonesia is also rich in diverse cultures. Indonesia is also rich of their human resources. The economic value can be profitable for the state, government and society. Some physics activities in the tourism sports of which are mountaineering, climbing, sport diving, mountain bike, out bond and traditional sport. Conversely, tourism events that can be collaborated with sports activities in Indonesia are Lake Toba festival, Serayu River Festival, Borobudur festival, etc. Finally, if the program is managed well in Indonesia, it will help this country to develop sports tourism sports and encourage people to participate in sports activities. It can also make potential athletes seedlings in various sports. Output of this activity is to encourage public awareness of the sport and responsible for sports performance.
\end{abstract}

Key words: Sports, tourism, Indonesia, development.

\section{Introduction}

Paradigm of sports tourism began to flourish in the world in the early 2000s, which was marked by the publication of the Journal Sports Tourism. However, the development and commercialization of the sports industry has started in 1984. After the implementation of the 1984, Olympic Games in Los Angeles marked the success of the organizing committee, which was a great benefit of holding the Olympic Games.

In general, understanding sports is a series of systematic activities to encourage and develop human's physical, spiritual and social potential factor [1]. One of the exercises in sport is sport recreation that refers to a sport that is done by people with a penchant and ability to grow and develop in accordance with the conditions and cultural values of the local community for health, fitness and pleasure. Further, according to DISR (Department of Industry, Science and Resources), tourism is a pleasant activity that a man

Corresponding author: Soedjatmiko, M.Pd., research field: sports management. E-mail: jatmiko_unnes@yahoo.com. carried out with the purpose of escaping from routine work, residence and any kind of activities or places with scientific activities. It is usually carried out during their stay at the destination and by using the facilities that were made to meet their needs [2]. It is believed that tourism is a pleasure personality activities, satisfaction, knowledge, health, exercise, rest and pilgrimage. Sports tourism in Indonesia is part of the sports industry as a whole. Sports tourism is tourism which used sports activities as a means to an end. If it developed properly, it has potential to be developed in the interests of economics, social and educational.

Sports Tourism in Indonesia into policies developed as a part of the sports industry. Indonesian sports industry revival began in 2006, although the rules of the sports industry has been there before. Government through the Ministry of Youth and Sports launched in 2006 as a revival of the Sports Industry, sports tourism as a part of it. Sports tourism has economic value and can bring benefits to the State, the government and local communities. In many countries, Sports and Tourism are started to develop one by one. One of the 
recent advanced developments is the emergence of sports that are used as both the object as well as an attraction for tourists. Such types of sports are offered primarily in natural tourism sites, such as mountains, lakes, rivers and sea, as they offer the charm of natural beauty as well as cultural and local wisdom. So many countries have not show any improvement on spending for the purposes of travel, tourism, sports and leisure time continues to grow. This potential is possible in the countries who has tourism as a commodity, including Indonesia.

Bali province is one of the provinces in Indonesia which have developed the most successful sports tourism. An international scale event had also been successfully held in Bali Island. Previously in 2008, multi Bali Asian Beach Games event had been successfully held. It was the first event that equalized some modified sports held on the beach. Indonesia has many competitive advantages in the market to offer tourism destinations, including climate conducive to outdoor activities, various sports activities, quality sports facilities; well and heavily developed tourism infrastructure in the international promotion increase as the nation's sports and tourist destinations. Even the fact that the Indonesia's seasons are opposite of world tourism, which provides a variety of opportunities in various fields. But we have to manage our potential to make maximum benefit for the country as a whole. Although there are so many opportunities in the field of sports tourism broader, some sectors and some places seemed possible to have a special potential and to develop. Sports and Tourism are two disciplines and studies which can be combined.

The combination of both disciplines is considered to be beneficial to double the power and its positive effect. There are two elements in the implementation of sport tourism which are the tourism and the sports itself. Some of the problems that arise are as follows: (1) How is the potential for sports tourism in Indonesia? (2) What are obstacles faced by sports tourism in Indonesia? (3) What are the challenges faced to develop sports tourism in Indonesia?

\section{Discussion}

Some tourism figures give some definitions of the types of tourism in Indonesia. Based on the motives and objectives [3], types of tourism are divided into 6 sections: (1) Cultural tourism is activities that travelers will be interested primarily in the style of art and culture in their own country so that they might be interested also to visit the sights of the same kind in other countries as far as finances and ability allow; (2) Medical tourism is tourist activity that is mostly done by those who have health like traveling from one place to another either because the doctor's advice as well as habit after feeling tired and bored of the monotonous work; (3) Sports tourism is a tourist activity mostly done by those who are involved either directly or indirectly in various types of sports activities such as mountain climbing, shooting, hunting, fishing, riding a car/motorcycle, boarded the plane/helicopter, highlands winter sports in the Alps, and the regatta water skiing in the North Sea, etc. (4) Tourism Trade and Politics are the participants consist of various trade and political figures or regions/countries that went with the purpose of gaining political advantage and trade; (5) Tourism sciences is a participants held meetings or research in various fields of science and knowledge to the regional, national, as well as to the international level; (6) Social tourism is a aims to help those who want to travel but perhaps not in terms of finances and often gets help from government agencies/tourism either directly or indirectly.

Tourism is further divided into seven types according to the tourism object, namely: Cultural Tourism, Recuperation Tourism, Commercial Tourism, Sports Tourism, Political Tourism, Social Tourism, and Tourism Religion [4]. While tourism is divided into five groups by means: recreational tourism, cultural tourism, health tourism, sports tourism, and tourism conference. Further in understanding sport tourism, a detailed sport tourism framework that not 
only illustrates a tentative sport tourism typology (based upon competitiveness, recreation, activity and passivity) but also a method which organization can utilize in order to identify current and future sports tourism development is considerably needed [5].

Sport tourism is divided into two types [6]. The first is sport tourism for big sport events. The actual implementation of sport tourism for big sport events are Olympic Games, World Cup Football, World Championship Boxing, Basketball World Championships, etc. The second one is sport tourism of the practices. It is a kind of sport tourism for those who want to do their own activities by aiming at a pleasure outcome. The examples are: mountain climbing, hunting, rafting, etc.

\subsection{Government Policies}

The government has issued a policy on sports industry like: Sportswear creative product development and various sports equipment educational, recreational sports, and sports achievements of national and international standards. Further, the government also develops various sport championship events under the category of Olympic game, various championship competitions, as well as festivals including recreational sport, community sports and traditional sports. There are also extreme sports, including adventure sports, which is integrated with arts degrees, traditional culture, contemporary arts, natural resources, and promotion of tourism. Sport development consultancy is also developed in line with the growing development of health and fitness club. In addition, there is the growing development of sport information and communication media, spurring promotional, and marketing in the sport industry at home and abroad. Increased capacity and capability of the sports industry from an economic perspective, the development of sports industry geared to accelerate the reduction of unemployment, employment opportunities and business opportunities for young entrepreneurs in rural and urban areas.

\subsection{Potential Sports Tourism in Indonesia}

Legal basis implementation Sports tourism in Indonesia is based on the law No. 3 of 2005 on the national sports system. In the article 18 of the sports industry, sports tourism is stipulated as a part of the sports industry. Second Act No. 17 of 2007 concerning the long-term development plan mentioned in the sports industry development plan like: improve the quality of human resources; improve the governance of the sports industry; improve quality standard of sports industry, sports event in accordance with national and international quality standards. Expanding distribution center industry gym equipment is able to produce creative products of national and international standards. The creative production will then increase the intensity and quality of sport for recreation events, sport tourism, nautical sports, world-class extreme sports, and also the enhancement of both role and contribution of organizations, institutions, and sport clubs in organizing sports events and sport equipments.

Indonesia is a country with diverse natural resources. It has the highest number of islands in the world, amounting to approximately 13,000 pieces, and the longest coastline in the world. Besides, Indonesia also has amounts of both active and inactive volcanoes as well as mountains which spread from Sumatera to Papua and many rivers with their own special characteristics.

Indonesia also has the most beautiful sea in the world that spread in all parts of Indonesia, such as Bunaken in Sulawesi Island, Raja Ampat in Papua Island, Karimujawa in Java Island, etc. There are also several considerably famous beaches in the world, such as Kuta Beach, Sanur Beach, Lombok Beach etc. Those places belong to natural tourist destination in Indonesia that should be preserved and developed. Indonesia's population now consists of approximately two hundred and sixty souls. This number is the fourth most populous in the world. However, from this excessive amount of people, Indonesia only has approximately $65 \%$ of a potential work force. The 
population is the basic capital in the development of sport tourism in Indonesia if it can be managed with the major supporter of moving sport tourism in Indonesia. Besides, with the condition of Indonesia that consists of various ethnic groups, religions and customs is also a tourist attraction. It has big potential because each tribe has different habits and different cultures.

There are many historical relics which are rare relics, and a world heritage, such as Borobudur temple, Prambanan temple, Mendut temple, etc. Tourist places like this has the potential to develop sports tourism. Tourist attraction can be used as a special attraction.

\subsection{Existing Constraints}

Sports tourism in Indonesia is hampered by the lack of information and promotion of tourist destination spot. The lack promotion of tourist attractions on the development of sports tourism has big impact. A sustainable promotion is a shared task between tourism and creative economy ministry with youth and sports ministry.

Promotion has been done in the conventional way and just evolved from mouth to mouth. Many tourist attractions can be potential to develop into a place for tourism and sports industry, but has not been handled well. Promoting in destination country has been done intensively through various ways either through formal channels, as well as non-formal channels. The attempt to introduce our tourism places to the world through campaign has been done by the government but is still considered to be inferior if it is compared to Malaysia and Singapore.

The lack of access to the site inhibits desire that parties will follow and organize the event. Access is the key to the development of tourist attractions that will develop later. The lack of infrastructures also causes the slow development of tourist attractions. Damage to roads and bridges are also an obstacle that must be overcome by relevant ministries. The lack of infrastructure is also recognized by the Ministry of tourism and creative economy. Another flaw is presented in the quality of human resources that is still relatively low. Low human resources makes our competitiveness is low compared to other countries. Low competitiveness will also hinder the development of sport tourism in Indonesia. Therefore, Indonesia needs a better management of human resources to improve competitiveness since increasing the competitiveness of an organization will accelerate the goal to be achieved [7].

\subsection{Sports Tourism Development Opportunities in Indonesia}

In the era of globalization, distance between countries is shortened by the existence of many technologies on transportation. It will also accelerate progress of tourist destination spots. As a result, we will need more tourist attractions to promote sport tourism in Indonesia.

Indonesia's position as a crossroad between two continents and two oceans is also a challenge in developing sport tourism in Indonesia. How to utilize the geographical position of Indonesia as a tourist destination and sports tourism is a challenge that must be answered by all stakeholders of tourism and sports. Failure utilization of this strategic position will only make Indonesia as consumer tourism and sports tourism.

Furthermore, security assurance is also one of the important parts to optimize Indonesian sport tourism. We need a conducive and secure condition to invite tourists and tourism sports participants. To be able to successfully promote Indonesian sport tourism, both the government and society must be able to work hand in hand to ensure the security of an event. However, to ensure safety is not easy, moreover, when we consider the vast territory, diverse ethnic and religious belief which are also potential to invite instability. Stability needs to be improved in order to compete with other countries.

One more significant part in promoting Indonesian sport tourism is the need to master science and 
technology as the basis of the development of sport tourism in Indonesia. In the modern era, the development of science and technology become the human needs. Modern people cannot be separated from the invention of technology and information. As a consequence, the need for science and technology is increasingly urgent to be improved. Marketing, implementation and evaluation of the event take the latest technology. Many tourists often spend their time on vacation and do sports, yet never leave their business. It means that the infrastructure and personnel need a reliable provider to operate it.

Good infrastructure will spur the development of tourism and sports tourism in a region. Instead, the lack of infrastructure development of the two major is an obstacle to the above. Therefore, the development of infrastructure should be a priority that will develop tourism and tourism spots in Indonesia. It takes considerable funds to develop infrastructure. But this development can be used as an investment and medium term and long term.

\section{Conclusion}

Empowering sport tourism in Indonesia can also bring benefit into the development of other tourisms, such as nature as well as cultural tourism. The development of sports tourism can provide great benefits to the government and society. Indonesia has a great potential in resources natural, custom, culture and population. Indonesia tourism and sports development is constrained by the lack of promotion, the low quality of human resources, the difficulty of accessibility and existing infrastructure. The challenges of developing sports tourism in Indonesia is the era of globalization, geographical position, security, mastery of science and technology and infrastructure improvements. If successful sports tourism will be developed, it will promote a tourism destination and improve people's lives around.

\section{References}

[1] Harsuki, H. 2012. An Introduction to Sport Management. Jakarta: Rajawali Press, 7-9. (in Indonesian)

[2] DISR (Department of Industry, Science and Resources). 2000. Towards A National Sports Tourism Strategy (Draft). Canberra: Commonwealth of Australia, 50-3.

[3] Hall, C. M., and Weiler, B. 1992. "Adventure, Sports and Health Tourism.” In Special Interest Tourism, edited by Weiler, B. and Hall, C. M. London: Belhaven, 141-58.

[4] Yoeti, O. A. 1987. An Introduction to Tourisms. Bandung: PT. Angkasa, 112-8. (in Indonesian)

[5] Gammon, S., and Robinson, T. 2003. "Sports and Tourism: A Conceptual Framework." Journal of Sports Tourism 8 (1): 21-6.

[6] Gibson, H. J. 1998. "Active Sports Tourism: Who Participates Leisure Studies?" Leisure Studies 17 (2): 155-70.

[7] Richard G., and Abdourazakou, Y. 2008. "The Management of Sporting Innovation at Decathlon. Between Rationality and Chaos." In The Engineering of Sport 7, edited by Estivalet, M., and Brisson, P. Springer-Verlag Paris, 597-611. 